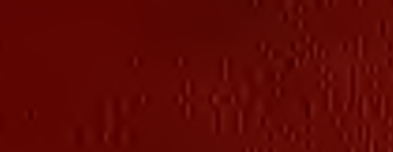

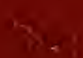

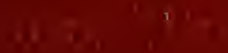

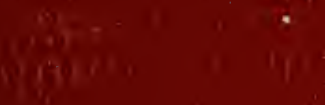

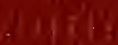

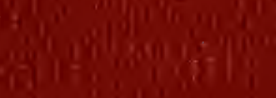

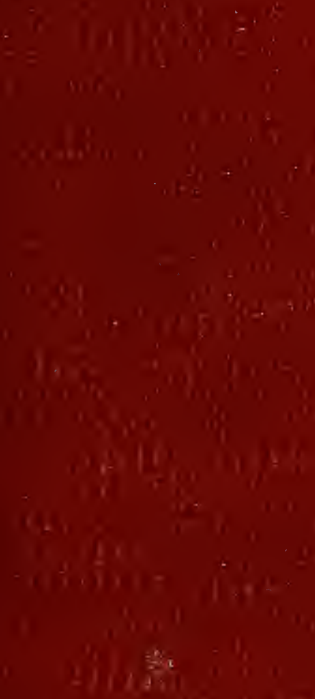
1)

119.

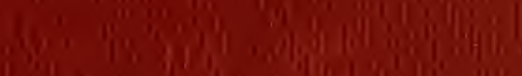
,

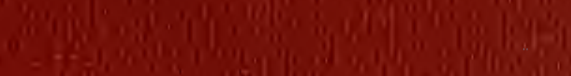
(n) is

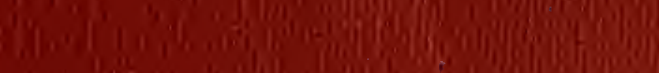

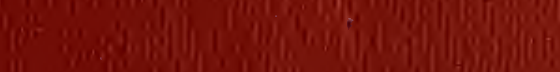

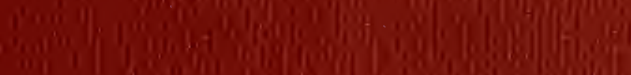
" J J 


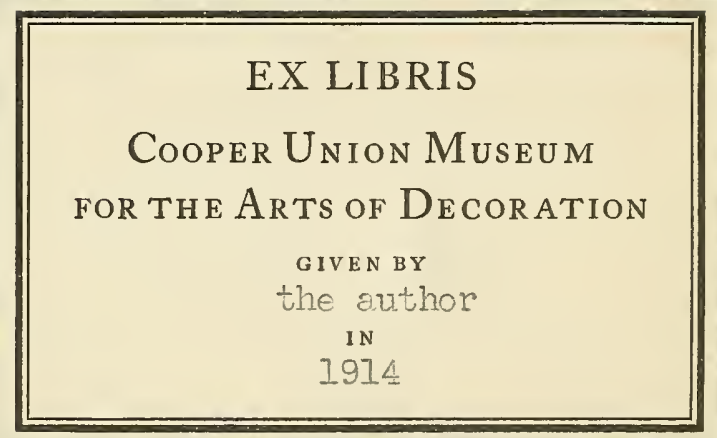








THE

FURNITURE COLLECTORS' GLOSSARY 

THE WALPOLE SOCIETY

\title{
THE \\ FURNITURE COLLECTORS' \\ GLOSSARY
}

\author{
BY \\ LUKE VINCENT LOCKWOOD
}

三.2.

NEW YORK

PRINTED FOR THE SOCIETY

M C M X I I I 


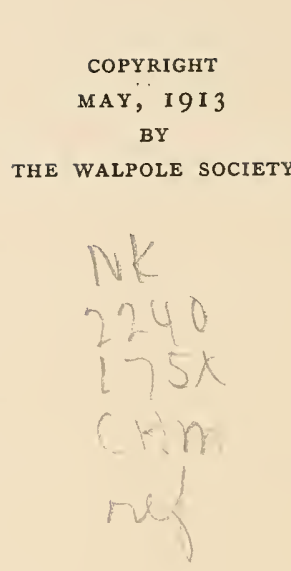




\section{THE WALPOLE SOCIETY}

EDWin A. Barber

Francis H. Bigelow

Dwight Blaney

Richard A. Canfield

Thomas B. Clarke

George M. Curtis

John Cotton Dana

H. W. ERving

Harry Harkness Flagler

Hollis French

Norman M. Isham

Harry Watson Kent

Luke Vincent Lockwood

George S. Palmer

Arthur Jeffrey Parsons

Marsden J. Perry

Albert Hastings Pitkin

Charles A. Platt

Frederick B. Pratt

Charles H. Tyler

Theodore S. WoOLSEY

George Parker Winship 



\section{P R E F A C E}

THE membership of the Walpole Society comprises collectors of 1 various kinds of objects of art, chiefly of American workmanship, paintings, furniture, silver and ceramics. Being desirous of aiding one another in these pursuits, certain of the members have prepared a series of glossaries of terms used in collecting, actuated, also, by the belief that such works would fill a real need, as found not only by themselves, but by the fraternity of collectors at large.

The present volume is compiled with the idea of bringing together in convenient form the words used in the Cabinetmaker's Art. There are a number of words not heretofore to be found in any dictionary but which are used among collectors. Architectural words are defined in their furniture sense and are illustrated from actual pieces of furniture or from books by the early cabinetmakers.

A glossary of terms for the collector of furniture at first thought might seem to be unnecessary, since, as the captious might contend, the dictionaries ought to give all of the words here brought together, and more too. So they do, no doubt, but not in compact form with a view to the vagaries of the peculiar genus collector; nor classified, nor yet with cross-references-important consideration, very, where niceties of terms are concerned, and exact differentiations. For him who loves such items this book is intended, the kind of person referred to by that distinguished gentleman and collector, from whom the Walpole Society takes its name, in his Preface to the "Anecdotes of Painting 


\section{P REF A C E}

in England": "From the antiquarian I expect greater thanks; he is more cheaply pleased than a common reader: the one demands to be diverted, at least instructed-the other requires only to be informed." 
GL O S A R Y 



\section{G L O S A R Y}

A

AвAcus.-The uppermost member of a capital.

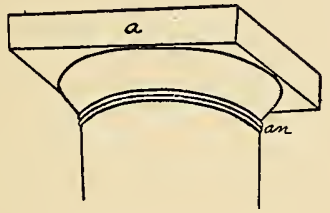

Acanthus.-An ornament which conventionalizes the leaf of the

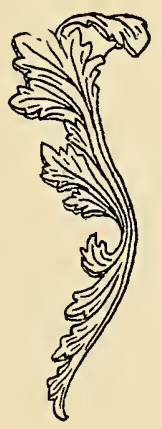

acanthus spinosus or acanthus mollis.

Acroterium.-A small pedestal placed on the apex or at each
ACroterium.-Continued.

of the lower corners of a pediment to hold a statue or orna-

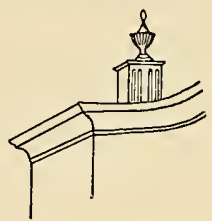

ment. Also sometimes used to denote the ornament.

Adam, Robert.-An architect and designer but not a cabinetmaker. His style was neoclassic. His influence was very marked on the furniture of England from I76o-8o. See Style.

Almery.-See Cupboard.

Ambry.-See Cupboard-Almery. Andiron.-Metal utensils for use in fireplaces to hold burning logs. Called also fire-irons. Angel-Bed.-See Bedstead. Angular Dutch Foot.-See Foot. 


\section{G L O S S A R Y}

Annulet.-A na r row flat moulding encircling a column. Called also a fillet or a listel. Anthemion.-A flat or low relief decorative group of flower

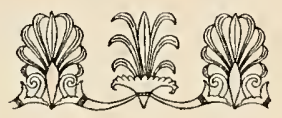

or leaf forms, often called honeysuckle ornament.

Applied.-Attached to and not a part of the surface. Applique. Applique.-A decorative ornament applied to an object or structure.

Arabesque.-A decorative scroll work in geometrical design and

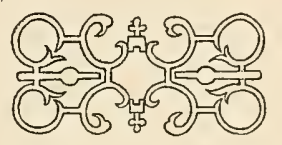

frequently consisting of fanciful figures, flowers and foliage.

Arcature.-A small arcade formed by a series of little arches. It may be blind or open.

ARCH.-A real or apparent structural member disposed vertically in the form of some curve to span an opening or recess.
ARc H.-Continued.

The inner line or surface of the arch is called the intrados; the outer, the extrados. Flat.-An arch having a horizontal intrados.

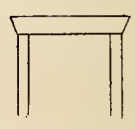

Ogee.-An arch each side of which is composed of an ogee curve meeting at the top in an acute angle.

Pointed.-An arch in which two curves meet at the crown at an angle.
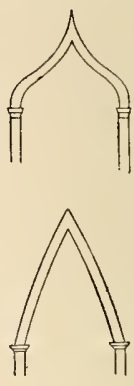

Round. - An arch having a semicircular intrados.

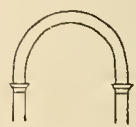

Archivolt.-The mouldings on the vertical outer face of the arch ring.

Armotre.-See Cupboard.

Astragal.-A half round moulding; a small torus. See Moulding.

Atlantes.-Figures of men used in place of columns or pilasters to support an entablature. Telamones, see also Caryatides. 
Bahut.-See Chest.

BAIL.-The loop or ring of a handle.

BALDACHIN.-A canopy.

Ball Foot.-See Foot.

Baluster.-A short pillar.

Banister.-A colloquial name for a slender baluster.

Balustrade.-A series of balusters supporting a rail.

Bandy Leg.—See Leg.

Banister.-See Baluster.

BAROQUE.-A term of reproach applied to anything excessive, extravagant or in bad taste.

BASE.-The division of the column on which the shaft stands. It generally includes the plinth and the base mouldings.

Basin Stand.--See Stand.

BeAd.-See Moulding, Astragal.

Beaufatt.-See Cupboard.

Bedstead.-The frame of a bed.

This includes the posts and head and foot boards if any. Angel-Bed.-An open bedstead without posts.

Claw and Ball Foot.-A bedstead, the posts of which ter-
Bedstead.-Continued. minate in an animal's or bird's claw grasping a ball. Cupboard.-A bedstead which folds against the wall when not in use.

Field.-A bedstead with rather low posts and curved tester. Sometimes called tent bedstead.

French.-A bedstead with roll ends and without posts, sometimes called sleigh bed.

Half Headed.-A bedstead with short posts and without tester. Oak.-I 7 th century or earlier four-post bedstead of oak. Usually with head board and wooden tester top, carved or paneled.

Tent.-Same as Field.

Tester Top.-A bedstead having a tester.

Trundle.-A small bedstead on wheels or castors intended to roll under a larger bedstead when not in use.

BeNCH.-See Settle and form.

Bergère.-See Chair. 


\section{GLOSSARY}

BeveL.-The inclination of one surface to another of the same body. Cant.

Bible Box.-See Box.

Bilection Moulding. - See Moulding.

Block Front.

Curved.-A surface as the front of a desk or chest of drawers cut in block form,

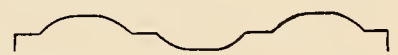

raised and depressed, the edges of the blocks being curved.

Square.-A surface as of the front of a desk or chest of drawers cut in block form,

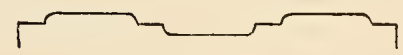

raised and depressed, the edges of the blocks being square or nearly so.

BомвÉ.-See Chest of Drawers.

BonneT.-The top section of the case of a tall clock.

Bonnet Top.-An inclosed scroll

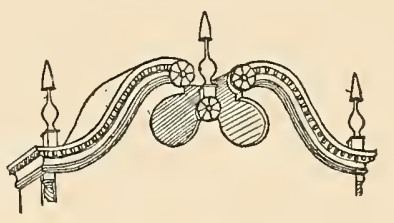

top. It is also used to denote the top of any piece which is inclosed.
BoOKCASE.-A piece of furniture in one or two carcasses fitted with shelves to hold books.

Boss.-A protuberant ornament.

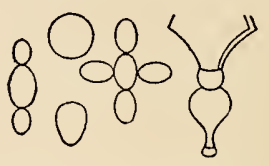

Nail Head.-An applied orna-

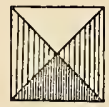

ment, square, with all four sides chamfered to a point. Rectangular.-A boss rectan-

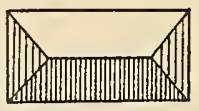

gular in shape having all four sides chamfered.

Split Spindle.-A spindle split

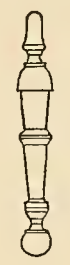

longitudinally and applied to a surface.

Turtle Back.-An oval boss ap-

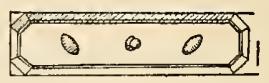

plied to the surface as an ornament. 


\section{GL O S S A R Y}

Box.-A case made of wood or other substances, made to hold small articles.

Bible.-A box, usually of oak, used as a receptacle for books and papers.

Casket.-A small box intended to hold valuables.

Desk.-A box similar to a Bible box, sometimes fitted with pigeonholes and compartments.

Knife.-A form of box, the inside of which is covered and pierced in shapes to hold in an upright position knives, forks and spoons.

BRACKET.-A projecting support, the outer edges of which usually form a right angle; also used to denote the ornament sometimes found at the angle
Bracket.-Continued. formed by the leg and rail of a chair.

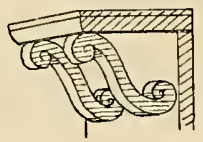

Bracket Foot.-See Foot.

Brasses.-See Handles.

Broken Pediment.-See Pediment.

Buffet.-See Cupboard.

BuHL.-See Inlay.

Bulbous.-In bulb form. Said of turned work.

Bureau.-Used in the United States synonymously with chest of drawers.

Bureau.-See Desk.

Bureau Chamber Table.-See Desk, Cabriole legged.

Butterfly Table.-See Table. 
Cabinet.-A small piece of furniture containing drawers or compartments-Étagère.

Cable-Moulding.-See Moulding.

Cabochon.-A convex ornament, usually round or oval, with a plain center.

Cabriole Leg. - See

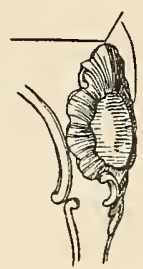
Leg.

Canal Moulding.-See Moulding.

CANePhores.-Figures of women bearing baskets on their heads; used in place of columns.

Cant.-A surface sloping from, or making an obtuse angle with, a surface adjacent to it. Bevel.

Canteen.-Box for liquor bottles. Cordial case.

CAPITAL.-The head of a column.

Composite.-The capital of the composite order, the Roman adaptation of the Corinthian order, which combines the
Capital.-Continued.

Corinthian and Ionic capitals.

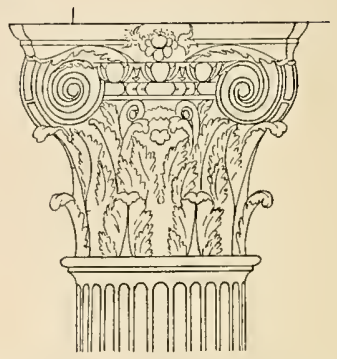

Corinthian.-The capital of the Corinthian order, one of the three orders used by the

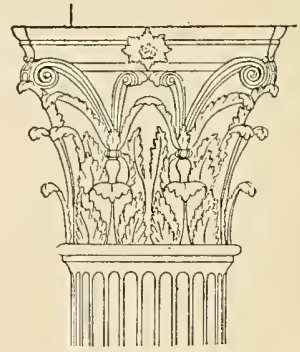

Greeks, composed of acanthus leaves and scrolls. It may be of Greek or Roman form. The latter is the more common. It appeared in the Renaissance in a great variety of forms. 
Capital.-Continued.

Doric. - The capital of the Doric order, composed in the

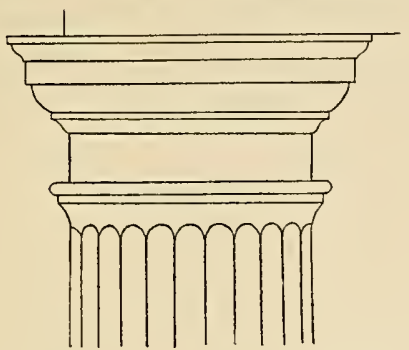

Greek form of abacus, echinus and annulets. In the Roman form a bead and fillet may take the place of the annulets. The form shown is that used by Chippendale.

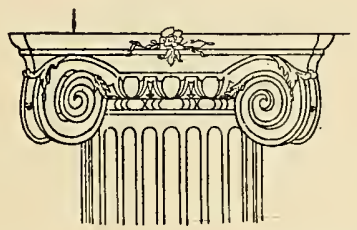

Ionic.-The capital of the Ionic order. The chief characteristics are volutes and egg and dart moulding.

CARcass.-The frame or skeleton of a piece of furniture.

Cartouche.-An o r n a mented shield or tablet sometimes in the form of a scroll of paper or leather.

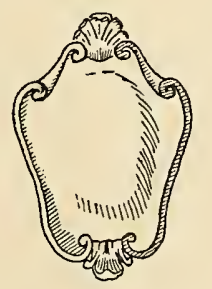

Carving.-The art of cutting wood into ornamental forms. Cameo.-A delicate raised carving resembling cameo cut-

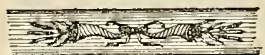
ting found on the Sheraton and early Empire styles.

Flat.-Cutting wood so that the pattern is formed by

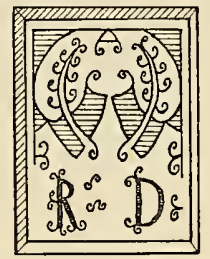

sinking the ground and leaving the face of the panel for the design.

Incised.-Cutting the wood so

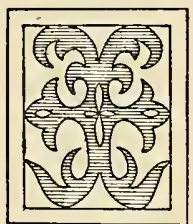

that the design is cut into the surface.

Raised.-Cutting the wood so

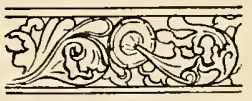

that the surface of the design lies in different planes. Relief.-Cutting the wood so that the design is embossed on a more or less uniform surface. 
CARving.-Continued.

Scratch.-Cutting the wood so

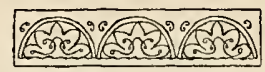

that the design is formed in outline by. fine lines.

CARyatides.-Figures of women used in place of columns or pilasters to support an entablature. See also Atlantes; Canephores.

Casket.-See Box.

Cavetto.-See Moulding.

Chaise Longue.-See Couch.

ChaIr.-A movable seat with a back.

Arcade.-A chair, the back of which is composed of arcatures.

Arm.-A chair with two arms or supports upon which to rest the arms. Elbow chair. Fauteuil.

Banister Back.-A chair, the

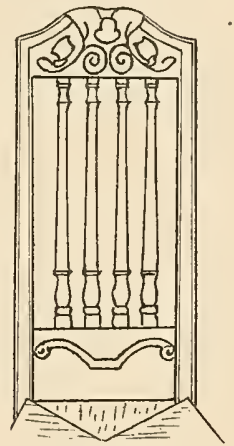

back of which is composed of vertical balusters.
ChaIr.-Continued.

Bergere.-An upholstered arm chair.

- Caquetoire. - An arm chair with a very high back, the

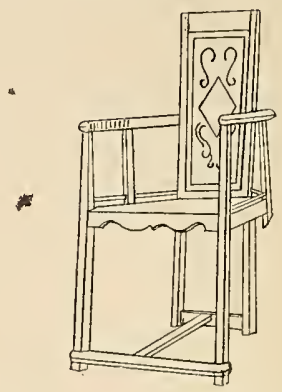

seat of which rakes toward the back.

Cane.-A chair, the back and seat of which are caned.

Carver.-An Americanism for a turned chair of the early seventeenth century, the back of which has three horizontal turning $\mathrm{s}$ an $\mathrm{d}$ three vertical spindles, between the two lower

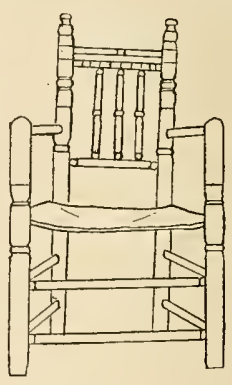
horizontal turnings. So called because of one owned by Gov. Carver.

Chauffeuse.-A low-seat chair. Chippendale Style. - A chair, the upper rail of the back of which is usually cut in 


\section{GLOS S A R Y}

Chair.-Continued.

a double cyma curve in the form of a bow. The splat

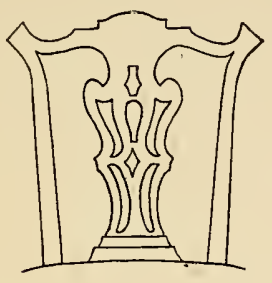

usually cut in more or less elaborate scrolls and curves, especially the $\mathrm{C}$ curve, and often ornamented with rococo and acanthus leaf carving. Also sometimes in Chinese and Gothic designs. Called after the cabinetmaker and designer of that name.

Cosey.-See Easy. Double.-See Settee.

Dutch Style. - A chair, the

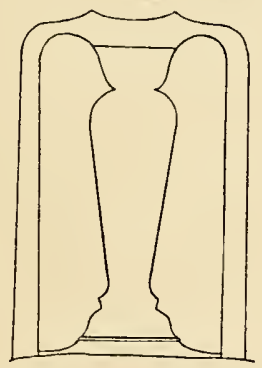

principal outline of which is composed of cyma curves. The top rail of the back curves down to the uprights forming the back.
Chair.-Continued.

Easy. - An upholstered arm chair with high back and spreading wings supported by the arms. Also called Wing chair and Cosey chair.

Empire Style.-A chair following the forms in fashion in the First French Empire in early Egyptian and classic forms.

Farthingale.-An early turned high-seat side chair.

Hepplewhite Style. - A chair, the back of which is in oval, shield or round form. Called after the cabinetmaker and designer of that name.

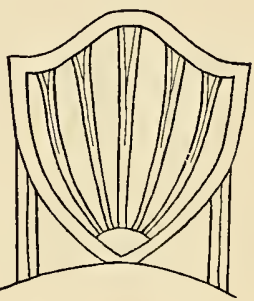

High Chair.-A chair standing on long legs, intended for use of a child.

Ladder Back.-A chair in Chip-

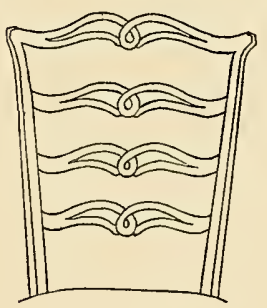

pendale style, the back of which, instead of having a splat, is composed of hori- 


\section{G L O S S A R Y}

Chair.-Continued.

zontal strips in similar design to the top rail.

Library.-An arm chair with a

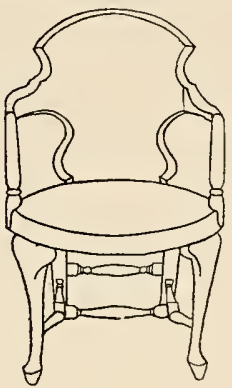

solid wood curved back, intended to be used at a desk. Rocking.-A chair, the lower ends of the feet being connected from front to rear with a curved strip of wood, causing it to rock.

Roundabout. - A chair having one foot at the front and at the back, and one on each

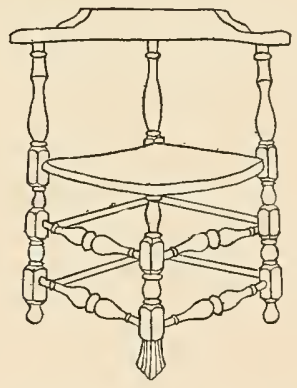

side. The back, circular in form, extending to each of the side legs.

Side.-A chair without arms.
Chair.-Continued.

Sheraton Style.-A chair usually with a rectangular back

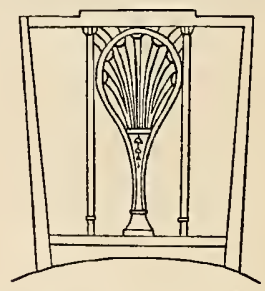

rather low and slightly raised at the center with a panel.

The style followed that of the Louis XVI period. Called after a cabinetmaker and designer of that name.

Slat Back. - A turned chair

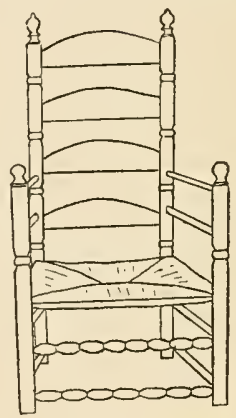

having horizontal slats between the stiles of the back. Slipper. - A chair with short legs.

Three Back.-See Settee.

Table.-A chair with a round, oval or rectangular back set in pivots, which enables it to be turned down upon the arms, thus forming a table. 
G L O S S A R Y

Chatr.-Continued.

Transition Style.-A chair combining the Flemish, turned

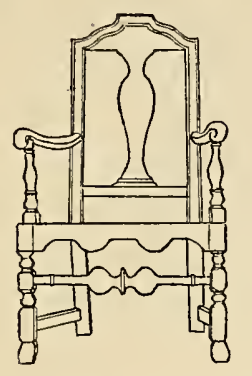

and Dutch styles and early eighteenth century.

Turkey Work.-A turned chair with low back, the seat and back of which are covered with Turkey work.

Turned, Leather Covered.-A turned chair heavily underbraced with seat and back covered with leather and often studded with brass nails. Turned Three-Legged.-Early form of chair with triangu-

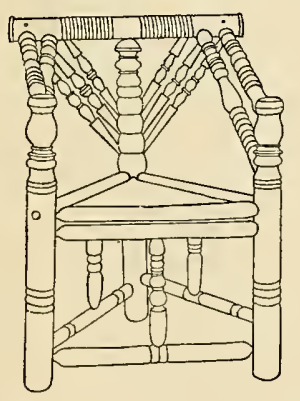

lar seat. One leg in front and two at back. All parts
Chatr.-Continued.

except the seat are usually of turnings. Originally called buffet chair.

Upholstered. - Any chair, the seat and back of which are covered with a fabric.

Wagon.-A low, short-legged, slat back, double chair, with

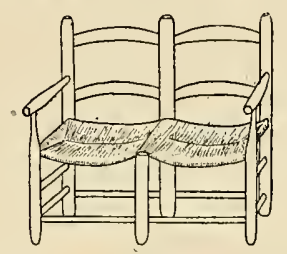

arms. So called because they were used as seats in wagons.

Wainscot.-An oak chair with paneled back, turned legs, and heavily underbraced. The stiles, cresting and panel often ornamented with flat carving.

Wheel.-A chair with round seat, semicircular back and

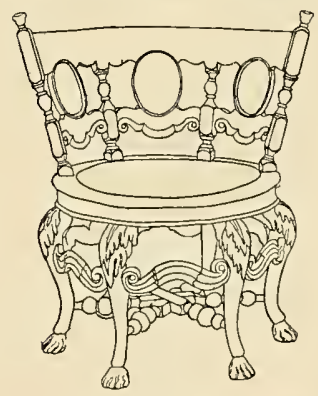

six legs. The underbracing crosses at the center, resembling spokes in a wheel. 
ChaIR.-Continued.

Windsor. - A form of chair, the back of which is composed of slender spindles ris-

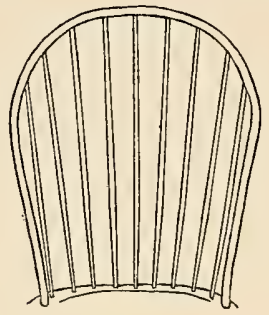

ing from the wooden seat and supporting a curved wooden top.

Windsor - Comb Back. - A

Windsor chair, the center spindles of the back project ing above the main back and supporting a head rest.

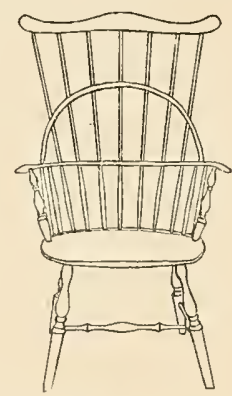

Windsor - Fan Back. - A Windsor chair, the spindles

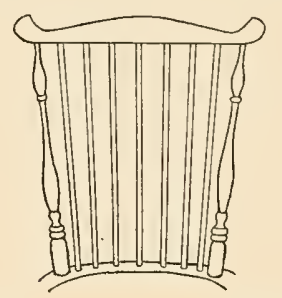

of the back of which support a curved wooden strip,
Chair.-Continued.

the spindles spreading in semblance of a fan.

Windsor - Wheel Back. - A Windsor chair having a center splat pierced in a circular design.

Wing.-See Easy Chair.

$W$ riting. - A chair having a large flat surface attached to the right arm.

$X$-Braced. - A chair, the underbracing of which is crossed.

$X$-Shaped. - An early chair made in the form of the letter $X$.

Yorkshire.-A seventeenth century chair, the back of

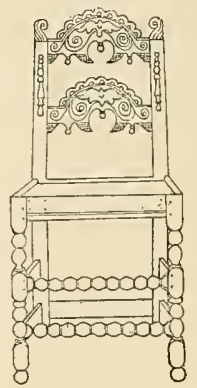

which opens in an arcade with spindles between. Arcade chair. Also applied to one of same period having two slats across the back, the upper edge engrailed, and the under side cut in peculiar scrolls suggesting Moorish style. 


\section{G L O S S A R Y}

Chamfer.-The corner of anything originally right angled, cut away so as to make an angle with the sides which formed it.

C HANNEL, - See

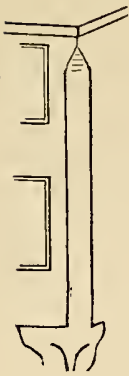
Moulding.

CHeck.-A pattern of squares of alternating colors.

Chest.-A box of considerable size with a hinged lid.

Bahut.-A chest with an arched top.

Carved.-A chest with either carved panels or carved stiles and rails, or both.

Connecticut. - A chest having three carved panels, the outer one carved in a tulip design, and the center one

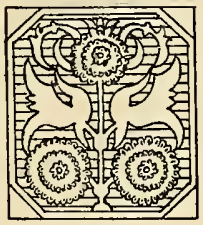

in an aster design, as in cut. Upon the stiles are applied split spindles, and on the drawers and end panels, bosses. An. Americanism, so called, because many of the same design have been found in the Connecticut valley.
Chest.-Continued.

Hadley.-A chest, the panels, stiles, rails and fronts of drawers of which are carved in a crude tulip design. The wood was usually stained in three colors, red, mulberry or purplish brown, and black.

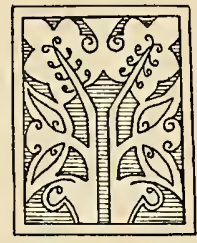

An Americanism, so called because many have been found at or in the vicinity of Hadley, Massachusetts.

Hutch.-A plain box or chest. Marquetry. - A chest ornamented with marquetry.

One-Drawer.-A chest having one long drawer below the box part.

Painted.-A chest painted in designs in imitation of carving. Usually made of pine. Paneled.-A chest ornamented in panel designs.

Three-Drawer.-A chest having three long drawers below the box part.

Two-Drawer.-A chest having two long drawers below the box part. 
Chest of Drawers. - A carcass containing drawers.

Ball Foot.-An early chest of drawers made usually of walnut or maple. The frame about the drawers has the single- or doublearch moulding and there is a large moulding at the base. The piece stands on four ball-shaped feet.

Block Front. - A chest of drawers, the front of which is cut in blocks, two raised and the center one recessed. Bombé.-A chest of drawers, the vertical outline of front and sides of which swell at

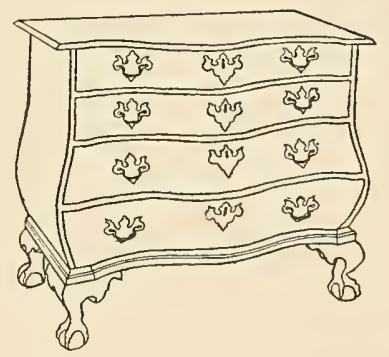

the bottom. The horizontal line being usually serpentine. Sometimes c alled Kettledrum.

Bracket Foot.-A simple form with straight bracket feet.

Bureau.-Original meaning was a desk. Now used in America synonymously with a chest of drawers.
Chest of Drawers.-Continued. Carved.-An early form contemporaneous with the oak chests and similarly carved. Chest on Chest.-A tall piece of furniture, consisting of two chests of drawers, one placed above the other.

Claw and Ball Foot.-A form popular in the Dutch and Chippendale periods, having either a straight or serpentine front, with animal or bird claws grasping a ball. Commode.-A chest of drawers in the French fashion.

Double. - Same as Chest on Chest.

Highboy.-See Chest of Drawers on frame.

Inlaid.-A chest of drawers, late 18th century, having inlay about the drawers.

Marquetry. - An early form ornamented with marquetry.

Ogee Bracket Foot.-A chest of drawers of the middle I 8 th century, having bracket feet mouldẹ in the cyma curve.

On Frame.-A chest of drawers raised from the ground on a frame with or without drawers, having either turned or bandy legs. Commonly called in America, highboy. 


\section{G L O S S A R Y}

Chest of Drawers. - Continued. Paneled.-An early form similar to the paneled chests.

Pillar and Claw.-A form common in the Empire style, having pillars either plain or carved on either side of the front and animal claw feet.

Reversed Serpentine Front.-A chest of drawers, the front of which is cut on a curve composed of two cyma or

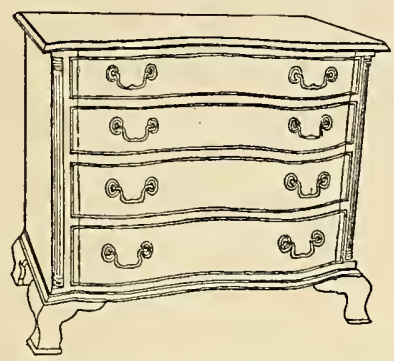

ogee curves so joined that the outer curves are convex and the inner curve is concave. Scroll Column.-A very late form having a projecting

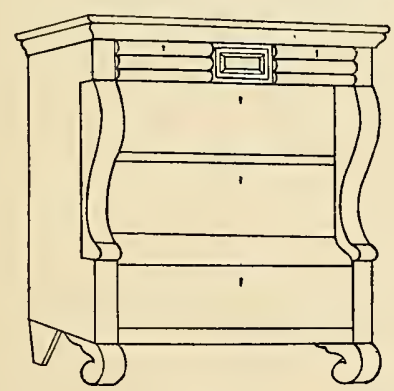

vertical scroll at either end of the front.

Serpentine Front.-A chest of
Chest of Drawers.-Continued. drawers, the front of which is cut on a curve composed of two cyma or ogee curves so joined that the outer'curves are concave and the inner curve is convex.

Swell Front.-A chest of drawers with convex front.

Chest on Chest.--See Chést of Drawers.

Chevron.-See Moulding.

Chippendale, Thomas.-Cabinetmaker in London. Author "The Gentleman and Cabinetmaker's Director." First edition published in 1754 . It is not known when he was born. He died in 1779. See Style.

Cinquefoll.-An ornament consisting of five cuspid divisions.

Classic.-Having the characteristics of ancient Greece or Rome.

Claw Foot.-See Foot.

Claw and Ball Foot.-See Foot.

Claw and Ball Bracket Foot. - See Foot.

Cleat.-A strip of wood fastened

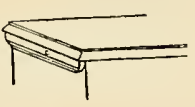
across a number of boards to hold them together.

\section{Clock.}

Banjo. - An early nineteenth century mural clock having a circular top for the dial supported by a rectangular 
Clock.-Continued.

pendulum case with raking sides and a projecting rectangular or round base.

Bird Cage. - See Chamber Clock.

Chamber.-A seventeenth century clock usually of brass, having a domed bell at the top and frets on three sides, partially hiding the bell. The dial has but one hand and the hour is divided into quarters instead of fifths. These clocks are intended to hang high on the wall on brackets. Called also Lantern and Bird Cage clocks. Chime.-A clock which strikes a chime on bells.

French. - An early nineteenth century clock made of wood, marble or alabaster, with four columns supporting an entablature with the clock dial supported between the two front columns.

Friesland.-A clock similar to the Chamber clock, except that the dial and ornaments are made of lead and painted.

Lantern.-See Chamber Clock. Musical.-A clock which plays tunes either on a string instrument or bells.

Portable.-See Table Clock.
Clock.-Continued.

Table.-A low clock in wooden case made to stand on a mantel or table. Also called portable clocks, mantel clocks.

Tall.-A clock having a long case to protect the royal pendulum.

Cock Bead Moulding.--See Moulding.

Coffer.-A large box or a chest, especially one used for keeping valuables.

Column.-A pillar. Used architecturally to denote a supporting member composed of a base, shaft and capital. Commonly applied to the shaft alone.

Engaged.-A column standing against the wall.

Fluted.-A column, the shaft of which is fluted.

Reeded.-A column, the shaft of which is reeded.

Comb Back Windsor Chair.See Chair-Windsor.

Commode.-A piece of furniture containing drawers. A chest of drawers.

Composite Order.-One of the orders of architecture, being a Roman adaptation of the Corinthian order, combining the capitals of the Corinthian and Ionic order. The column is fluted.

Connectrcut Chest.-See Chest. 
Console.-A bracket.

Console Table.-See Table.

Corbel.-A piece of wood project-

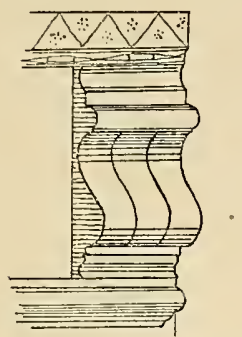

ing from a wall or the face of a piece of furniture and appearing to support some object. Corinthian Order.-One of the Greek orders of architecture. The capital is carved to represent acanthus leaves and scrolls. The column is fluted.

Corner Cupboard.-See Cupboard.

Cornice.-Any moulded projection which crowns the part to which it is affixed.

Corona.-A broad vertical projecting member of the cornice situated below the cymatium.

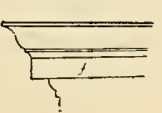

Couch.-A long seat usually upholstered, upon which one can recline. Sometimes called Day Bed.

Chaise Longue.-A couch with a chair back at one end.

Duchess.-A couch composed of an upholstered stool and two. upholstered arm chairs.
Court Cupboard.-See Cupboard.

Credence.-See Cupboard.

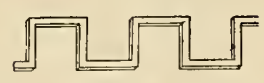

Crenelated.-Embattled.

Cresting.-An ornamental finish to the top of anything.

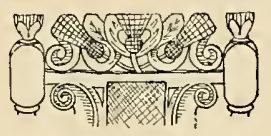

Cupboard.-A series of shelves inclosed in a closet or cabinet for keeping dishes, cups and other table ware.

Almery.-A cupboard intended to hold food; also called Ambry and Dole cupboard. Armoire.-A press or wardrobe not elevated from the floor.

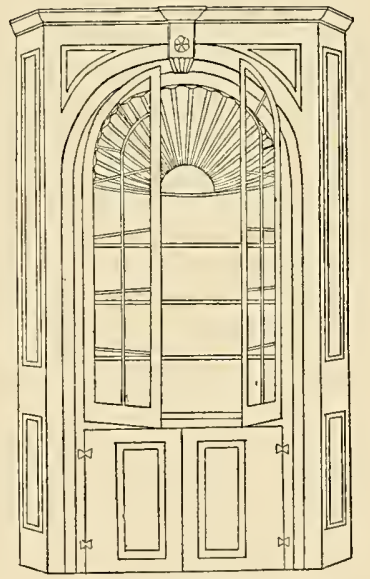

Beaufatt. - A colloquial name for a cupboard built into a room. 


\section{GL O S S A R Y}

Cupboard.-Continued.

Buffet.-A cupboard or sideboard for the display of plate and china.

Credence.-A shallow cupboard elevated on legs, upon which food was placed and tasted before serving. Also ecclesiastically a side table upon which was placed the bread and wine before it was consecrated.

Dole.-See Cupboard, Almery. Corner.-A cupboard built to set in the corner of a room. Beaufatt.

Court. - Originally an open cupboard, now used indiscriminately with Press cupboard.

Dresser.-A high cupboard, the upper portion made with open shelves and the lower portion enclosed with doors. Hanging. - A cupboard made to hang on the wall.

Kas.-A large Dutch cupboard with a heavy overhanging moulding, usually built with two doors above, paneled or painted, two short drawers below, and standing on ball feet.

Linen. - A cupboard built in two carcasses with upper and lower shelves or drawers covered with doors.
Cupboard.-Continued.

Livery.-An early form of cupboard with pierced or spin-

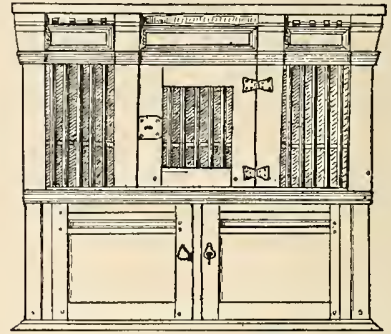

dled openings to give a free circulation of air. Intended to hold the family rations.

Of Drawers.-A cupboard with a series of drawers, often enclosed with doors.

Press.-The most familiar form of early cupboard. The top

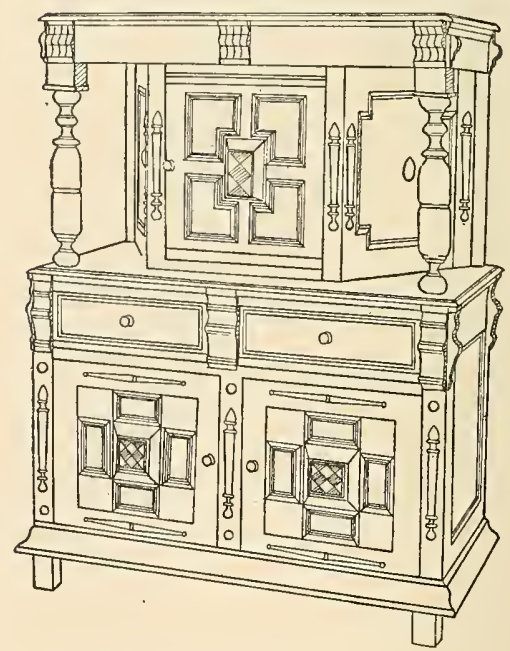

usually supported by columns with a small cupboard below and the base 


\section{G L O S S A R Y}

Cupboard.-Continued.

fitted with long drawers or cupboards.

Side.-A cupboard similar to the corner cupboard, built to stand on the side wall of a room.

Wardrobe.-A cupboard within which to hang clothes.

Cupped Leg.-See Leg.

Curved Block.-See Block.
Cusp.-The intersecting point of

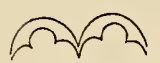

the small arcs of the trefoil, quatrefoil, etc.

Cyma Rećta.-See Moulding.

Cyma Reversa.-See Moulding.

Cymatium.-That portion of a cornice which contains a cyma curve. 
DAY BED.-See Couch.

Dentil.-One of a series of little rectangular blocks used between mouldings.

Desk.-A piece of furniture upon which to write. Formerly called Bureau.

Ball Foot.-A slant top desk of early eighteenth century design, with single- or doublearch mouldings on the frame about the drawers and standing on four ball feet.

Block Front. - A slant top desk, the fronts of the drawers and sometimes the lid of which are cut in blocks, two raised and a center one depressed.

Bookcase Top. - A desk in two carcasses, the upper one built to hold books.

Bureau.-Original meaning was a desk. Now used in America synonymously with a chest of drawers.

Cabinet Top.-A desk in two carcasses, the upper one having doors and the interior
Desk.-Continued.

fitted with compartments and pigeonholes.

Cabriole Legged.-A slant top desk standing high from the floor on cabriole legs, similar to a lowboy. Called contemporaneously bureau dressing table.

Drop Front.-A desk, the writing part of which is covered by a vertical wooden slab which falls and is held horizontal by chains, thus forming a surface upon which to write.

Escritoire.-Same as desk. Corrupted into Secretary.

Fire Screen.-A narrow desk in the form of a fire screen, with a vertical lid which falls to form a writing surface.

Knee-Hole.-A desk with the center of the lower part recessed or open.

On Frame.-A slant top desk standing high from the floor on turned legs, which are underbraced. 


\section{GL O S S A R Y}

Desk.-Continued.

Secretary.-See Escritoire.

Reversed Serpentine Front.-A slant top desk, the front of the lower part of which is cut in a curve composed of two cyma curves, so joined that the outer curves are convex and the inner curve is concave.

Serpentine Front.-A slant top desk, the front of the lower part of which is cut in a curve composed of two cyma curves, so joined that the outer curves are concave and the inner curve is convex.

Slant Top.-A desk, the lid of which is on an angle to the front, and when open is supported by pulls.

Standing. - Any desk which stands on the floor as distinguished from the desk box, or one to be used in the lap.

Table.-A desk having a flat top upon which to write. A writing table.

Tambour.-A desk, the writing portion of which is concealed behind a tambour cover.

Desk Box.-See Box.
DiAPER.-A pattern consisting of a constant repetition of one or more simple figures.

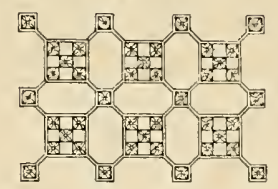

Dog Tоотн.-See Moulding.

Dole.-See Cupboard.

Doric Order.-The earliest order of Greek architecture, the capital consisting of an abacus echinus and annulets unornamented. See Capital.

Double-Arch Moulding.-See Moulding.

Dove-TaIL. - A tenon cut in the form of a reversed wedge to sink into a mortise similarly cut.

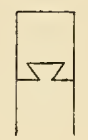

DoweL.-A wooden pin to connect two parts. Usually a separate rod set part way into each part.

Drawbore Pin.-The pin which secures the tenon in the mortise. It was usually square, driven into a round hole.

Dresser.-See Cupboard.

Drop.-An affixed pendent ornament.

Drop Brass.-See Handle.

Dutch Foot.-See Foot. 
E

Easy Chair.-See Chair.

Echinus.-A member of the Doric capital which lies be-

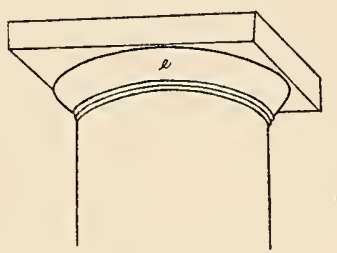

tween the abacus and the neck of the column.

Egg \& Dart Moulding.-See Moulding.

Emвossed. - Ornamented with raised work.

Empire Style.-See Style.

ENCARPA.-A decorative ornament in the form of a festoon of fruit or flowers.

ENGRAILED.-A series of concave curves. The reverse of scallop.

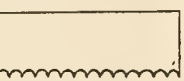

ENGRAVED.-Cut with a sharp instrument.
Entablature.-The horizontal mass carried upon columns or pilasters. It is divided into

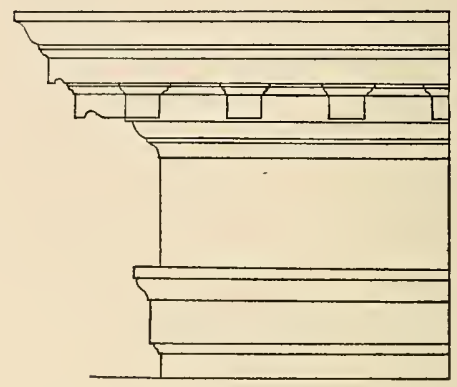

three parts in the order named. The architrave, the frieze and the cornice.

ENTASIS.-The swell of the shaft or column of either of the orders of architecture.

Escritoire.-See Desk.

Escutcheon.-A plate to finish a keyhole. Used also to designate a shield.

Etagère.-See Cabinet.

EXTRADOS.-The outer line or surface of an arch. 
FAN BAck.-See Chair-Wind- Festoon.-Continued.

sor.

Fan Pattern.-Carving or inlay in the form of an open fan.

FASCES.--The ancient insignia of a Roman magistrate. A bundle of elm or birch rods in the center of which is an axe. Used in late Sheraton and early Empire styles as ornament, carved or inlaid.

FAscra.-A flat architectural member.

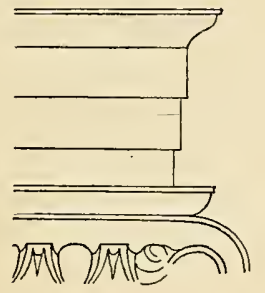

Fern Pattern.-A design resembling a simple fern.

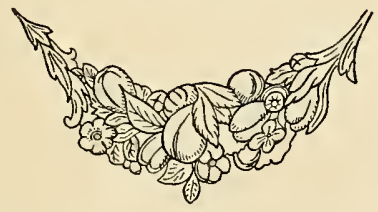

Festoon.-An ornament in the form of a garland or wreath of flowers, fruits or leaves suspended by the ends.

Field Bedstead.-See Bedstead.

Fillet.-A small flat fascia separating mouldings.

Finial.-An upstanding ornament finishing the upper portion of a piece of furniture.

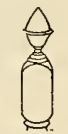

Flush.-A surface which lies in the same plane with the surrounding surface.

Flute.-A long vertical groove in a column or pilaster.

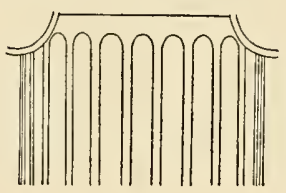

Reeded.-A flute, the lower section of which is filled in with reeds.

Flat Carving.-See Carving.

Flemish Scroll. - See

Scroll.

Flemish Scroll Leg.-See Leg. 


\section{G L O S S A R Y}

Flush Bead Moulding.-See Foot.-Continued.

Moulding.

Foliate.-Clothed with leaves.

Foot.-That portion of a piece upon which it rests.

Animal's Claw and Ball.-

The termi-

nal of a leg

which is com-

posed of an

animal'sclaw

grasping a

ball.

Ball.-A foot in oval or round form.
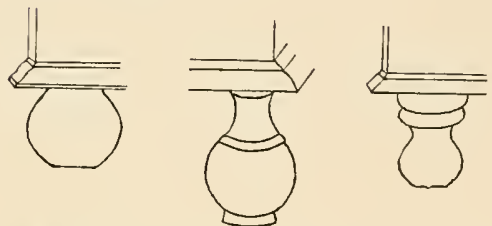

Bird's Claw and Ball. - The terminal of a leg which is

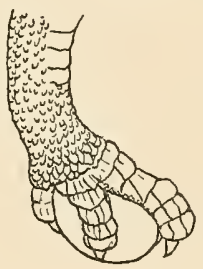

composed of a bird's claw grasping a ball.

Bracket. - A foot in bracket form.

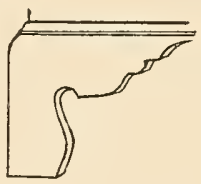

Claw.-A foot in the form of an animal's claw.

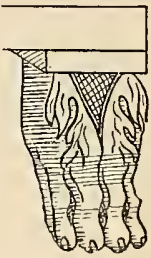

Claw and Ball Bracket.-A foot in bracket form, in the form

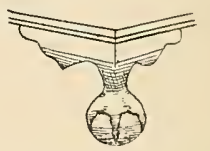

of a bird's claw grasping a ball.

Club.-See Foot-Dutch.

Dutch.-A foot in the form of a thickened disc standing flat on the floor or raised slight-

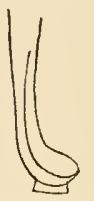

ly on a shoe; also called club foot, probably because of its close resemblance to a golf club.

Dutch Angular.-A Dutch foot whose sides form points, usually three in number, instead of forming a circle.

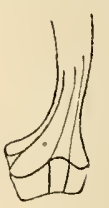


Foor.-Continued.

Dutch Elongated. - A Dutch

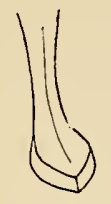

foot, the end of which is elongated to a point.

Dutch Grooved.-A

Dutch foot with shallow channels resembling a web foot.

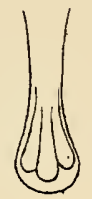

French.-A foot found on a

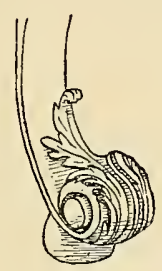

cabriole leg, finished in an outward foliated scroll.

French Bracket.-A slender elongated bracket foot, the outer edge of which curves out slightly.

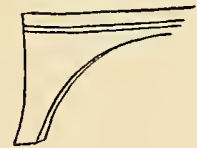

Hoofed.-A foot carved to resemble a hoof.

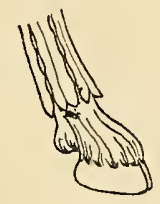

Foot-Continued.

Melon.-A ball foot in the form of a melon.

Ogee Bracket.-A bracket foot

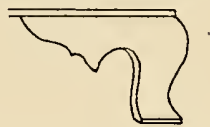

formed of a cyma reversa moulding.

Onion. - A ball foot in a form resembling an onion.

Rat Claw.-The terminal of a leg which is composed of a

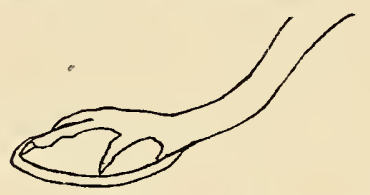

rat's claw, usually grasping a ball.

Scroll.-A terminal of a leg in the form of a scroll.

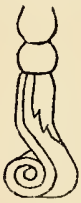

Shell.-A terminal of a leg in the form of a shell.

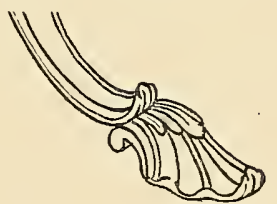


Foot.-Continued.

Spade.-A terminal of a tapering leg somewhat wider than the leg itself, in form resembling a spade.

Spanish. - A grooved inward turned scroll foot.

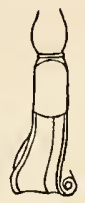

Stub.-A short tapering foot

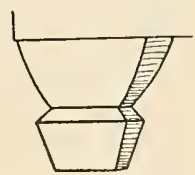

attached to the body of a piece.

Term.-A foot which widens

at the base-usually ornamented with carved foliated scrolls.

FOOT-BOARD. - The board between the two lower posts of a bedstead. Plain or ornamented.

Fox-Tailed Wedging. - A wedge driven into the end of a tenon in the mortise so

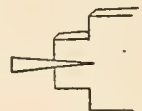
as to give it a dove-tail character to resist withdrawal.
Frame.-The skeleton structure of a piece of furniture.

Mirror. - The border for a mirror or picture.

French Foot.-See Foot.

French Bracket Foot.-See Foot.

FreT.-An ornament composed of

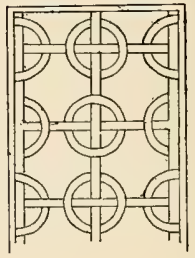

interlaced straight or curved lines.

Friesland Design.-Flat carv-

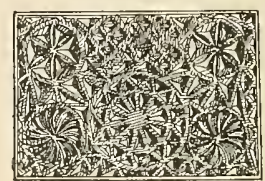

ing in circular and geometrical designs.

Frieze.-The central portion of

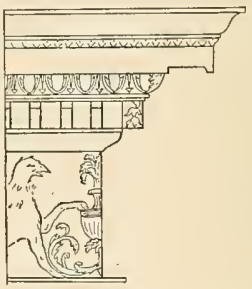

the entablature, usually highly ornamented. 
GaRLAND.-A wreath.

Girandole.-See Mirror.

GLYPH.-A short perpendicular fluting or grooving.

Godroon.-A convex rounded or-

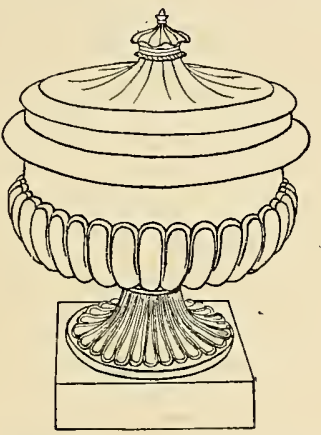

nament with carved top and bottom.

GoTHIC.-That form of mediæval architecture characterized by the pointed arch.

Grasshopper Legs.-See Legs. Greek Key Pattern.-See Meander.

GrILLE.-A grating or lattice work.
Groove.-A channel or long hollow.

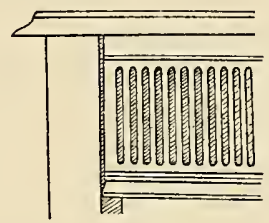

GuERIDON.-A tall slender stand intended to hold a candlestick. Guilloche.-An ornament com-

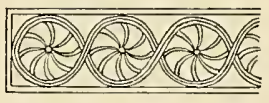

posed of interlaced curved lines.

Gutra.-One of a number of

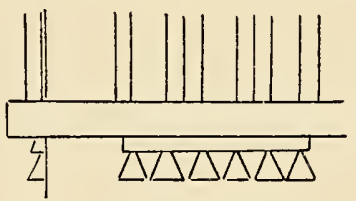

small circular ornaments on the under side of the regula. 


\section{$\mathrm{H}$}

Half Headed Bedstead.-See Bedstead.

HANDLE.-That part of a piece of furniture by which it can be grasped.

Drop Brass. - An early form consisting of a plate of metal and a pendant

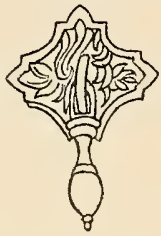
fastened to a piece by a wire loop.

Early Engraved.-That form of handle which consists of a plate of brass, the surface of which is engraved, a bail and two wire loops holding the bail.

Glass.-A handle in the form of a glass knob, used in the early nineteenth century.

Hinged.-A handle without a plate having an oval-shaped

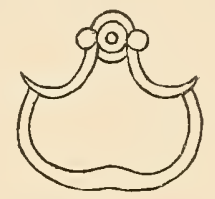

pendent bail attached to a single post on a hinge.
Handle.-Continued.

Insert Ring.-A handle in the form of a round or oval

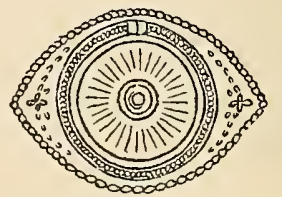

plate or rosette with a pendent ring fastened at the top. Open Work. - A handle, the

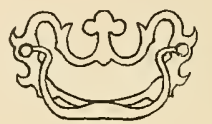

plate of which is pierced or cut in a design.

Oval._A handle, the plate of which is oval and the bail is

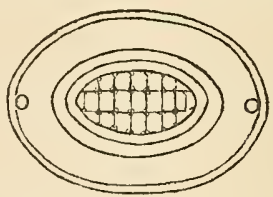

suspended from the outer sides of two posts.

Plate and Bail.-A handle consisting of two small oval or round plates attached by posts between which is suspended the bail. 


\section{GLOS S A R Y}

Handle.-Continued.

Plate and Ring.-A handle consisting of a plate and ring.

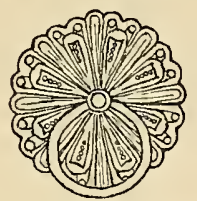

Rosette.-A handle or knob in the form of a rosette.

Willow.-A form of handle, the plate of which is cut in

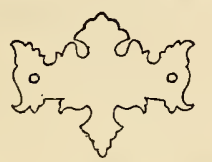

irregular waving lines and extends below the suspended bail.

Wood.-A handle in the form of a knob of wood.

Hanging Cupboard.--See Cupboard.

HARD Wood.-See Wood.

Hadley Chest.-See Chest.

Harlequin.-A piece of furniture containing secret compartments which can be released by springs.

HEAD BoARd. - The board between the two upper posts of a bedstead. Plain or ornamented.

Hepplewhite, A.-The name of a Cabinetmaker who published designs in England in 1788. First name is supposed to have been Alice. See Style.
HerRing - Bone. - A border formed of two narrow strips

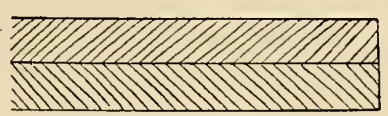

of wood so cut that the grain of each is diagonal and join at an angle.

Highboy.-See Chest of Drawers on Frame.

Hinge.-A means of connecting a door or a table leaf with its frame so that it will swing thereon.

Cock's Head. - A hinge, the

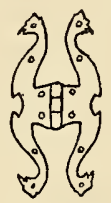

leaves of which are cut to resemble a cock's head.

H.-A form of hinge, the leaves of which are lengthened, and when open forms a letter $\mathrm{H}$. Loop.-An early form of hinge consisting of two loops interlocked.

Strap.-An early simple form of hinge with two leaves, the outer ends of which are

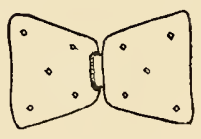
wider than the ends which join.

Hip.-See Knee.

Нuтch.-See Chest. 


\section{$\mathrm{I}, \mathrm{J}, \mathrm{K}$}

Incised Carving.- See Carving. Interrupted Arch Pediment.

INCRUSTATION.-The act of forming a crust or hard-coated surface.

INDENTATION.-A zigzag moulding.

INLAY. - An ornamentation

formed by inserting one material into another which has been cut out to receive it.

Buhl.-A style of inlaid decoration perfected by Boule, consisting of inlays of wood, tortoise shell and metals.

Intarsiatura.-Italian word for inlay.

Marquetry. - Inlaid work in elaborate designs.

Mosaic. - An ornamentation formed by joining small pieces of wood or other substances to form a design.

INTAGLIO.-A figure cut into a surface so as to form a hollow. The opposite of cameo.

InTARSIATURA.- See Inlay.

INTERLACING. - Lines which

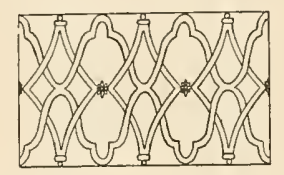

Interrupted Pediment.-See

Pediment.

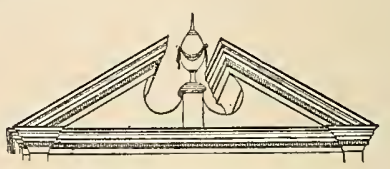

INTRADOS.-The inner line or surface of an arch.

Ionic.-One of the five orders of architecture, the chief characteristic of which is the volutes of the capital.

JAPANNING.- The art of coating a surface with a hard brilliant varnish.

Kas. - See Cupboard.

Key Stone. - A wedge - shaped

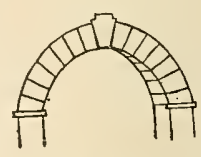
piece at the crown of an arch. KNEE.-The upper part of a cabriole leg, sometimes called hip or shoulder.

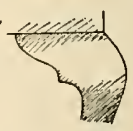

Knife Box.-See Box Knife.

KNoB.-A rounded projection.

weave under and over each other.

KNOP.-A bunch of flowers or leaves. 


\section{L}

LACQUER.-A varnish composed of shellac dissolved in alcohol and colored.

LATTICE.-A wooden structure composed of pieces of wood

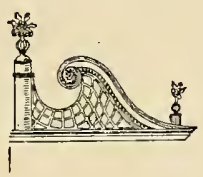

crossing and forming open work or a piece of wood cut in that manner.

LAURELING.-A long narrow leaf ornament.

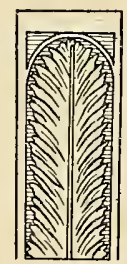

LEG.-The support of a piece of furniture, raising it from the ground. Bandy. - A leg whose outline is an elongated cyma curve; called also cabriole.

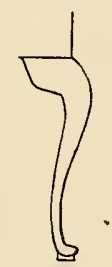

Cabriole.-Same as Bandy.
LEG.-Continued.

Cupped.-A turned leg, the upper part of which is turned to resemble an inverted cup.

Double Ogee Moulded. - A straight leg, the outer sur-

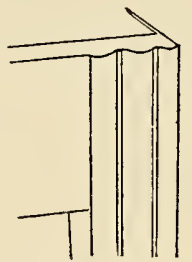

faces of which are moulded in form of two cyma curves. Elaborated Flemish Scroll.-A leg composed of a Flemish scroll with an additional foliated scroll just above the lower volute or at upper end of lower scroll. Flemish Scroll.A leg, the outline of which is a Flemish

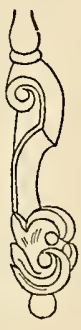
scroll. See Scroll-Flemish. 


\section{GLOS S A R Y}

LEG.-Continued.

Flemish Scroll, Out Turning Volutes.-A leg in form of a Flemish scroll with an additional volute at the top outward turned.

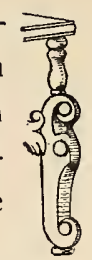
Fluted.-A straight leg with flutes cut in the surface. Grasshopper.-A card table is said to have Grasshopper legs when the two rear legs pull out on a hinged frame to support a top. Marlborough. - A tapering leg, either square or round, terminating in a spade foot.

Reversed S Scroll. - A leg, the outline of

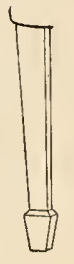
which is in the form of a letter $\mathrm{S}$ reversed.

$S$ Scroll.-A leg the outline of which is in the form of a letter $\mathrm{S}$.

Square. - A leg, the sides of which are square or rectangular.

Tapering.-A long square leg

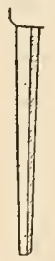

narrowing toward the bottom.

LEG.-Continued.

Trumpet Shaped. - A turned leg which resembles a trumpet with the large end up. Sometimes called Umbrella shaped.

Turned. - A leg turned on a lathe, either plain or with shaped sections.

Turned Bulbous.-A leg turned in bulb form.

Turned Knob.-A leg turned in a form resembling knobs.

Turned Null. - A leg turned in the form of balls threaded on a stick.
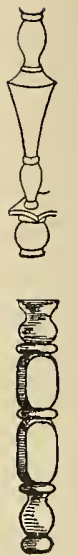

Turned Spiral.-A leg turned in spiral form twisted.

Turned Umbrella Shaped.See Trumpet shaped.

Turned Unilateral Double Scroll.-A leg composed of two scrolls turned the same way.

Turned Unilateral Flemish Scroll. - A leg composed of a Flemish scroll modified so that both volutes turn the same way.

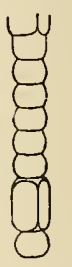


GL O S S A R Y

Linen Fold Pattern.-An Lozenge.-Diamond shaped.

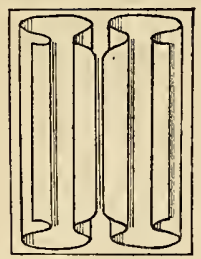

early design of carving made to represent folds of linen.

Livery CUPBOARD.-See Cupboard.

LOBE.-A section in rounded form. LowвоY.-See Table-Chamber.

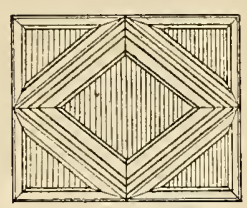

LunetTe. - A semicircular or

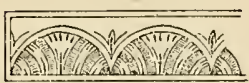

segmental aperture or outline. 
Marquetry.-See Inlay. Mascaron.-Mask. A human,

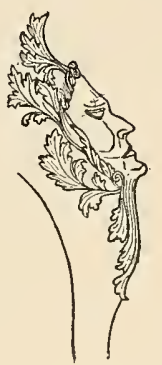

or partly human head used in decoration.

Meander Pattern or Greek FRET.-A pattern or border composed of lines or narrow

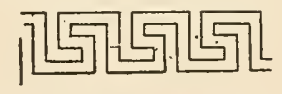

fillets at right angles to each other, commonly known as the Greek Fret or Key pattern.

MEdALLION. - A carved, moulded or stamped circular or oval work ornamented with flowers, heads, \&c.

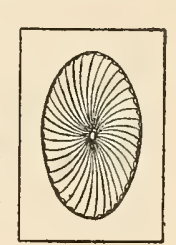

Mirror.-A polished surface intended to reflect an image. A glass, the back of which is coated with quicksilver.

The word is used commonly to denote the frame surrounding the mirror, as well as the polished surface.

Bilboa.-A style of mirror of the late eighteenth century, the distinguishing feature of which is that the frame is made of colored stone.

Bull's Eye.-A convex, concave or flat surface glass in a more or less ornate round frame.

Chippendale Style. - A mirror, the frame of which is ornately carved in scrolls, leaves, rococo, dripping water effects, and other motifs of the Chippendale style.

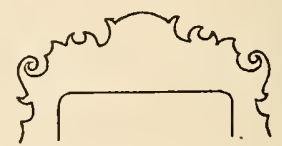

Cut Work. - A mirror, the 


\section{G L O S S A R Y}

Mirror.-Continued.

frame of which is cut out in various designs.

Diamond Cut.-A glass having a design cut in the surface. Dutch Style.-A form of cut work mirror having a tall cresting upon which gilded ornaments are often applied or inserted.

Empire Style.-A mirror, the frame of which has the characteristic form or ornament of the Empire period.

Filagree. - A mirror of the late eighteenth century, the frame and cresting of which are ornamented with flowers, \&c., in gilt made of wire and plaster.

Girandole.-A mirror frame attached to which are holders for candles or lamps.

Hepplewhite Style.-A mirror frame the form and ornament of which are in the characteristic Hepplewhite style.

Interrupted or Broken Pediment.-A mirror frame, the cresting of which is in the form of an interrupted pediment.

Mantel.-A long mirror framed in various styles, intended to be used over a mantel.

Marquetry. - An early mirror
MIRRoR.-Continued.

frame ornamented in marquetry.

Pier.-A tall narrow mirror.

Scroll Top.-A mirror frame, the cresting of which is in architectural form surmounted by two scroll mouldings.

Sheraton Style. - A mirror frame in the form and ornament of the characteristic Sheraton style.

Miter Joint.-A joint formed by the meeting of matched pieces in a frame or moulding.

MorTise.-A cavity cut to receive a tenon.

MouldiNG.-An ornamentation made by grooved or raised bands.

Astragal. - A small convex

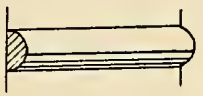

moulding semicircular in section. A small torus.

Bead. - A convex rounded moulding. Used also of

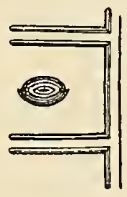

small mouldings, which an astragal never is. 


\section{G L O S S A R Y}

MouldiNG.-Continued.

Bilection.-A moulding which surrounds a panel and projects beyond its general surface.

Cable. - A bead moulding

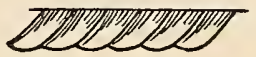

carved with a twist to resemble a cable.

Canal._-Two cock bead mouldings separated by a plain surface.

Cant.-A moulding composed of plain surfaces instead of curves.

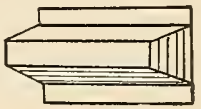

Cavetto.-A moulding with a simple concave profile usually quar-

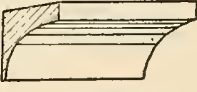

ter round. Also called a cove.

Channel.-A simple furrowed or grooved moulding.

Churn. - A zigzag moulding characteristic of Norman architecture.

Cock Bead.-A bead which projects beyond a surface.

Cove.-Same as cavetto.

Cyma Recta. - A projecting moulding consisting of a concave and convex arc. Called also ogee.

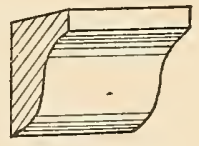

Moulding.-Continued.

Cyma Reversa. - A projecting

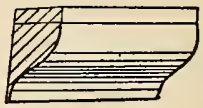

moulding consisting of a convex and concave arc.

Dentil.-An ornamented mould-

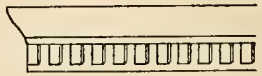

ing consisting of a series of little rectangular blocks.

Dog Tooth. - An ornamented moulding cut to form a series of pyramidal ornaments resembling a row of teeth.

Double Arch. - A moulding

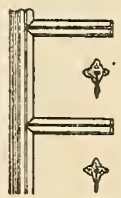

consisting of two small parallel half round mouldings.

Echinus.-A moulding in the form of the circular member which lies between the abacus and the top of the shaft in a Doric column. Also called in some forms a quarter round.

Egg छ Dart.-An ornamented moulding composed of 


\section{G L O S S A R Y}

Moulding.-Continued. oval bosses separated by darts.

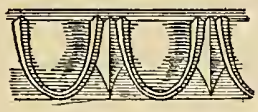

Flush Bead.-A bead mould-

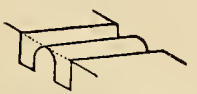

ing which is flush with the surface.

Ogee.-See Moulding-Cyma.

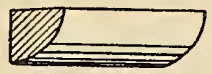

Ovolo. - A convex rounded moulding. A quarter round.

Pearl Edge.-A small mould-

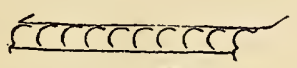

ed edge which resembles a string of pearls.

Quirk Bead.-A moulding consisting of a bead separated from an adjoining surface by a groove.

Quirk Bead, Double. - Same as Quirk Bead except that a

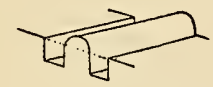

groove is cut on each side of the bead.
Mou Lding.-Continued.

Reel and Bead.-A moulding consisting of an oval alter-

$9000<000 \Longleftrightarrow 0$

nating with two or more pearl-shaped sections.

Scotia. - A concave moulding differing from a cavetto, in

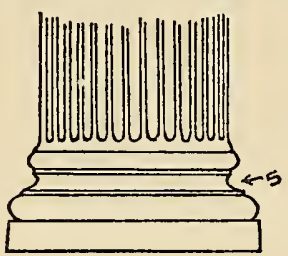

that it is a half round or greater.

Single Arch.-A moulding consisting of a rather large rounded moulding used about the drawers of late seventeenth century furniture.

Thumb. - A moulding usually worked on the wood and

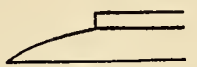

supposed to resemble the thumb nail.

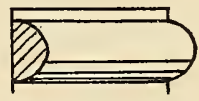

Torus.-A bold convex moulding. A half round.

Mosarc.-See Inlay.

Mudejar Style.-See Style. 


\section{$\mathrm{N}, \mathrm{O}, \mathrm{P}$}

NaIl Head.-See Boss.

Nebuly.-Having waving lines.

Night Stand.-See Stand.

Null.-A convex rounded ornament differing from godroon in that the latter is on a
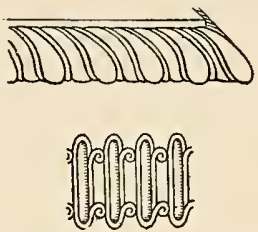

rounded surface, while a null is only on a flat or quarter round surface.

Ogee.-See Moulding.

Overlapping Drawer. - A drawer which overlaps the frame, usually finished with a thumb moulding.

Overt.-Open-a term used to designate the wings of a bird spread for flight.

Ovolo.--See Moulding.

Palm Pattern.-A design more or less closely resembling a simple palm leaf.

Palmated Scroll.-See Scroll.

Palmette.-A conventional ornament which represents a spreading leaf or fan.

PANeL.-A small surface framed in.

Raised. - A panel whose surface extends flush with or
PANeL.-Continued.

beyond the surrounding surface.

Sunken.-A panel, the plane of which lies behind its frame. Patera. - A flat, round, dish-

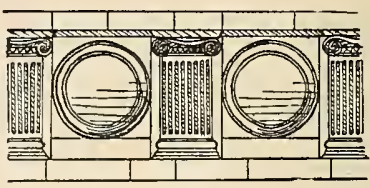

shaped ornament in bas relief, usually decorated.

Patina.-The color of a surface obtained by age and wear. Originally applied only to bronze, but now extended to include any material.

Pediment.-A triangular or curved gable or top with two

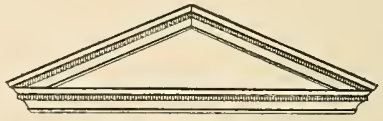

sloping sides which rests upon the entablature.

Broken.-See Pediment-Interrupted.

Interrupted Arch.-A pediment arch-shaped, the central portion of which is cut away. Also called broken arch pediment.

Interrupted.-A pediment with straight sloping sides, the central portion of which is 


\section{G L O S S A R Y}

Pediment.-Continued.

cut away. Sometimes called Broken Pediment.

Peg.-A wooden pin.

PENDANT.-An ornament consisting of leaves, flowers or fruit caught at one end and appearing to hang by its own weight.

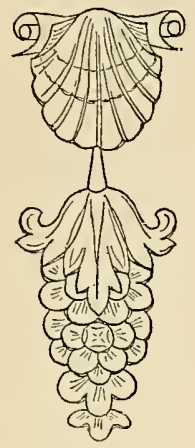

PIER.-A free standing square column.

Pigeon-Hole.-A little division in a desk for papers, \&c.

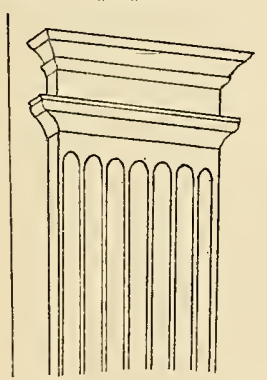

Pilaster.-A square column engaged in the wall.
PIN.-A small cylindrical piece of wood used to hold parts together.

Pineapple Pattern.-A design more or less closely resembling

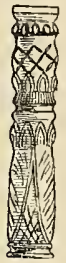

the fruit and leaves of pineapples and finials in that shape.

Planted On.-Attached to a surface.

Plate.-The flat portion of the handle which is held in place by the post.

Plinth.-The square member forming the lower division of

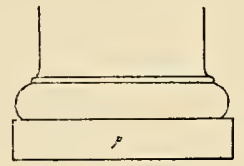

the base of a column. Thus applied to a square foot or leg. Post.-The terminals which hold the bail of a handle and which pass through the wood, securing the handle to the piece.

Press Cupboard.-See Cupboard. 


\section{Q, R}

Quadrant.-A quarter circle. Rabbet.-Continued.

Used to designate the metal of one piece to receive the edge mechanism on a drawer front which drops to form a desk surface.

Quarter Column.-A quarter section of a column used to fill in a chamfered or square recessed edge.

QUARTERED.-To cut in quarters. Used to designate a method of cutting a $\log$ of wood, especially one to obtain the greatest effect of grain.

QuATREFoll.-A piercing in four lobes.

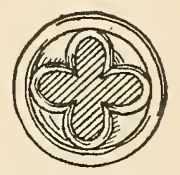

Quirked Bead.-See Moulding.

Rabbet, Rebate.-A groove cut on the edge of one board so

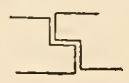

that it may join by lapping with another similarly cut, or a groove made along the edge of another.

RAIL.-The horizontal piece in a frame.

RaILING.-An open fret raised from the surface.

Raised Panel.-See Panel.

RAKISH.-Having an inclination from the horizontal.

REDENTED.-Having an edge composed of angles.

REEDING.-A number of semicircular ridges closely arranged in

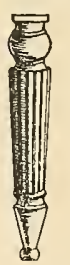

parallel order. The reverse of fluting in columns or pilasters. Also used to fill the lower part of a flute.

Reticulate.-Formed of network.

Reversed Serpentine Curve.A curve composed of two cyma 


\section{GL O S A R Y}

Reversed Serpentine Curve.Continued.

curves so placed as to form convex curves on the outer

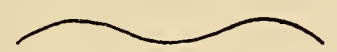

edges and a concave curve at the center.

Rising Sun Pattern.-A semicircular ornament with con-

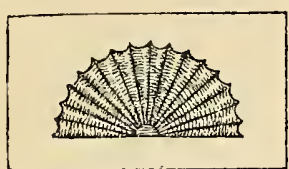

verging radiates. Also called sunburst.

Rococo.-A florid ornament consisting of scrolls, shells, rocks, water, buds and flowers thrown together without proper connection. A motif popular in the Chippendale designs, adopted from the French

\section{Rococo.-Continued.}

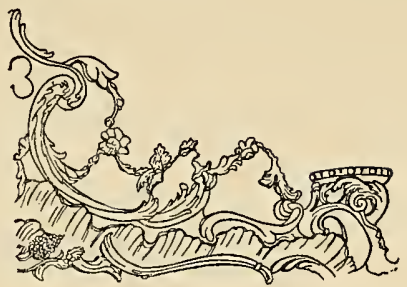

style known by the name of Louis XV.

Rose Pattern.-A design in the form of a conventionalized

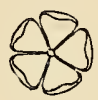

single rose found principally on oak furniture.

RosetTE.-An ornament in the

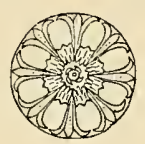

form of a rose, usually applied to the surface. 
Sausage Turning.-See Turn- Scroll.-Continued.

ing.

Scale Pattern. - Imbricated.

A form of carved ornament

\section{$m$}

made to represent scales of a reptile.

Sconce.-A candle-holder fixed to or attached to the wall or to a frame.

Scotia.-See Moulding.

SCREEN.-A piece of furniture with a flat surface, intended to cut off light or heat.

SCroll.-A convolved or spiral ornament.
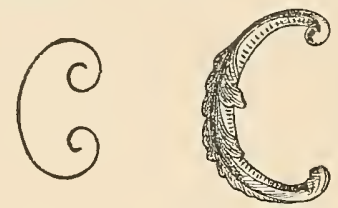

C.-A simple scroll in the form of the letter $\mathrm{C}$.

Frilled.-A C scroll having outer projecting edges carved.
Elaborated Flemish.-A Flemish scroll with an addi-
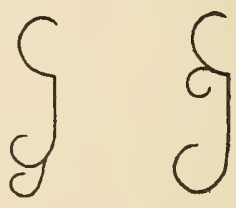

tional foliated scroll just above the lower volute or at the upper end of lower scroll.

Flemish.-A scroll consisting of a reversed $\mathrm{C}$ scroll joined

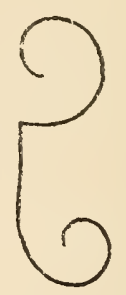

to a $\mathrm{C}$ scroll in such a way as not to form a flowing line. 
Scroll.-Continued.

Palmated. - A scroll with branching radiates. $\mathrm{A}$ term

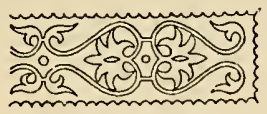

sometimes used to describe a Spanish foot.

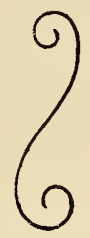

Reversed S. - A scroll in the form of a reversed letter $S$. Running Dog. - See Scroll Vitruvian.

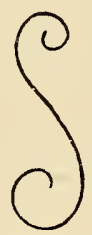

S.-A scroll in the form of a letter $\mathrm{S}$.

Unilateral Double. - A scroll

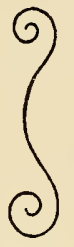

whose volutes both turn in the same direction.
Scroll.-Continued.

Unilateral Flemish.-A Flemish scroll so modified that both volutes turn in the same direction.

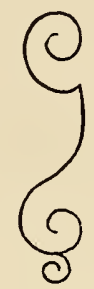

Vitruvian.-An ornament consisting of a series of con-

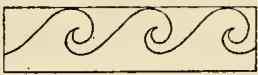

voluted scrolls. Also called Running Dog.

Scroll Top.-A piece of furniture, the pediment of which is

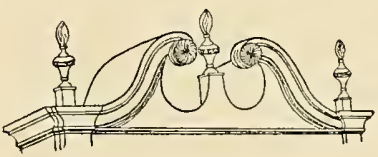

composed of two cyma curves. Separated at the center.

Secretary.-See Desk.

Serpentine Curve.-A curve composed of two cyma curves

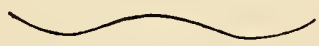

so placed that the outer curves are concave and the inner one convex. 
SerRated.-Notched on the edge like a saw. The word has been extended to mean any

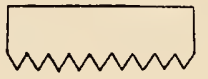

edge cut in a variety of curves or lines.

Settee.-A long backed seat with arms. It is meant for more than one person.

Causeuse. - A small settee. Love seat.

Double Chair. - A seat consisting of two chair backs with arms.

Three-Back Chair.-A seat consisting of three chair backs with arms.

Love Seat.-A settee in form of a large arm chair; Causeuse.

SETTLE.-A seat with backs and arms. It is meant for more than one person, made entirely of one material. The back sometimes swings on pivots and turns down to form a table. A bench.

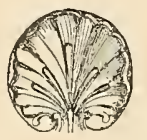

Shell Pattern.-An ornament more or less closely resembling a shell.
Shoe.-A thin block on the bottom of a foot.

SideboARd.-A long table with drawers or cupboards upon which to display articles to be used on the dining table.

Side Cupboard.-See Cupboard. SHEARER. - A cabinetmaker of about I788, whose designs closely resembled those of Hepplewhite.

Sheraton.-A cabinetmaker who published a book of designs in 179I. His style was at first similar to the French Louis XVI and later that of the French Empire.

Slat Back.-See Chair.

SofA.-A long upholstered seat with back and ends upon which one may recline.

SoffiT.-The under horizontal surface of a moulding.

SPANDREL.-The space between the extrados of an arch and the

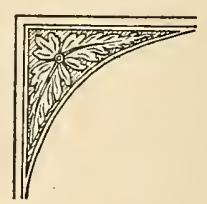

head over it; also any one of the corners left on a square clock face by the circular dial.

Spanish Foot.-See Foot. 


\section{GLOS S A R Y}

SPINDLE.-A small turned baluster.

Splat.-That portion of a chair back which joins the center of the top rail with the seat and forms the section against which the back rests.

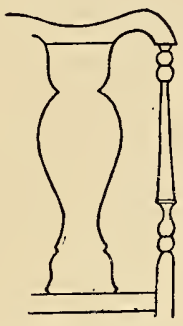

SPLAY.-A surface making an oblique angle with another surface. Same as Bevel or Chamfer, but refers to a large surface.

Split Baluster.-A baluster cut in half longitudinally.

Split Spindle.-See Boss.

Spoon RACK.-A hanging receptacle for holding spoons.

SQUAB.-A cushion, later meaning a cylindrical cushion.

STAND.-A small table.

Basin.-A small stand usually in tripod form, the top of which is intended to hold a basin. Candle. - A small stand intended to hold a candle; also called Gueridon and . Torchere.

Night.-A stand intended to
STAND.-Continued.

be used beside the bed, usually containing a cupboard.

Tea Kettle.-A low stand intended to hold a tea kettle.

Tripod.-A small table, the top supported by a column and three branching feet.

Wash.-A stand constructed to hold a wash bowl and pitcher.

STILE.-The vertical member of a piece of framing into which the horizontal member called a rail is fitted.

Stоol.-A seat without a back.

Foot.-A low stool upon which to rest the feet.

STYLE.

Adam.-A style named after Adam Brothers, who were architects and designers but not cabinetmakers. The style is a revival of the Roman classic, popular at Pompeii, and was popular throughout the last forty years of the eighteenth century.

Chippendale. - A style named after a cabinetmaker and designer of that name. The chief characteristics of this style are the mingling of inconsistent designs such as rococo, Gothic and Chinese. Surfaces are relieved by 


\section{GL O S S A R}

Style.-Continued.

carving in these designs and by frets. Chair tops are usually bow shaped. The later work in this style shows very strongly the classic revival. In vogue from about 1750 to 1775 .

Dutch.-This style was popular from about 1710 to I750. Its chief characteristics are the use of the cyma curve in the outline and the avoiding of straight lines whenever possible. The legs are cabriole and terminate in the club or the animal's or bird's claw foot on a ball. The ornament is acanthus leaves, swags and pendants of flowers or fruits, mascarons, cartouches and frets.

Empire. - A style adapted through the French from Egrptian models and neoGrecian influence. At first it was rather refined and delicate, but it gradually became ponderous with coarse carving in pineapple and acanthus leaf designs.

Hepplewhite.-A style named after a cabinetmaker and designer of that name. The style is classic but more deli-
Style- Continued. cate than that of Adam and shows the influence of the Louis XVI style. The chair backs are either oval, shield-shaped or round. The ornament is classic, free from the rococo influence. Both painting and carving are used. The style was in vogue during the last quarter of the eighteenth century.

Jacobean. - This style is divided into two periods, Early and Late. The Early style, which covers apparently the first sixty years of the seventeenth century, is massive, heavily underbraced, and the material is chiefly oak. Decoration was obtained from flat carving, inlay and applied bosses and split spindles. The farorite design was scrolls, rosettes, leaf and arabesque. Chairs were either of the wainscot or turned type, with high seats. The late Jacobean style covers the reign of Charles II. French and Continental influences are noticeable, and furniture, although bearing the same characteristics as the earlier period, is much lighter. The 


\section{GL O S S A R Y}

Style.-Continued.

heavy chairs were replaced by the light turned and cane seat and back ones.

Mudejar.-A mixture of Moorish and European styles of the seventeenth century.

Sheraton.-A style named after a cabinetmaker and designer of that name. The style is quite similar to that of Hepplewhite, but more closely follows the designs of the Louis XVI school. The last edition of Sheraton's books shows Egyptian designs similar to those in favor in France and known as the Empire style. Date I 790 to I 810 .

Transition.-A style in vogue from about 1700 to 1720 . It is a mixture of the "William and Mary" and "Dutch" styles, showing characteristics of each.

William Eo Mary.-The chief characteristics of this style are the turned legs and underbracing on chests of
Style.-Continued.

drawers and desks, which raises them from the floor. The ornament is either carving in foliated scrolls, or marquetry, but many pieces are plain, relying for their beauty on line and mouldings. Style in vogue 1690 to 17 I

STRAP-WORK.-A flat ornament compased of interlacing crossed and folded bands.

STRETCHER.-A bracing extending between the legs of a piece of furniture.

Sun-Burst.-A circular radiated design. It differs from the Ris-

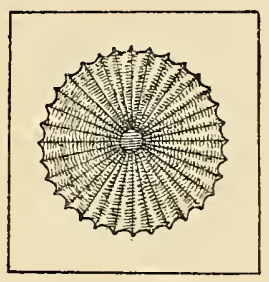

ing Sun pattern in that the former is a full circle and the latter is a half circle.

Swag.-Same as Garland. Festoon. 


\section{$\mathrm{T}, \mathrm{U}$}

TABLE. - An article of furniture consisting of a flat surface raised from the floor on legs.

Bandy-Leg.-A table, the legs of which are in cabriole form.

Breakfast. - A movable table with two leaves.

Bureau Chamber.-A piece of furniture in the form of a chamber table or lowboy, having a slant top desk in place of a table top.

Butterfy.-A table, the leaves of which are supported by large wooden brackets extending from the stretch-

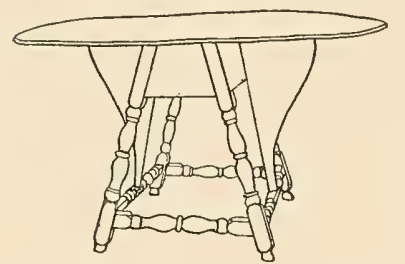

ers. The outer edge of each bracket is shaped in an elongated cyma reversa curve.

Gard.-A table for card play-
TABLE.-Continued.

ing, usually with a leaf which folds over and lies upon the table top when not in use.

Chamber.-A table having three to five drawers, commonly called a "lowboy.".

Console.-A table intended to stand against the wall, the slab top of which is supported by consoles.

Dining.-A table upon which meals are served.

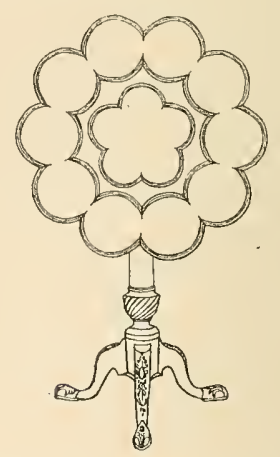

Dish-top.-A tripod table, the top of which is cut in moulded circles.

Drawing.-An early table, the top of which is composed of 


\section{GL O S S A R Y}

TABLE.-Continued.

three slabs of wood superimposed, two of which draw out from the ends, thus enlarging the surface of the table.

Dressing.-A table intended to be used for toilet purposes; sometimes called a rudd table.

Drop-leaf.-A table with hinged leaves.

Extension.-A dining table with extending frame, to which leaves can be added.

Folding. - An early form of table, the frame of which folds.

Framed. - A table without leaves.

Gallery.-A table, the top of which is encircled by an applied fret or band.

Game. - A table, the top of which is arranged for two or more games.

Gate-leg. - A drop-leaf table, having eight or more legs; each leaf supported by at least one pair of legs joined by an upper and lower stretcher.

Harlequin.-A table, the interior of which when released by a spring lifts up, disclosing compartments, drawers, $\& c$.
TABLE.-Continued.

Kidney Shaped.-A table, the top of which is kidney shaped; called in French "Haricot."

Night.-A small table with a cupboard, used beside the bedstead.

Pembroke.-A breakfast table with two leaves, the top of which is often inlaid or painted in elaborate designs.

Pie Crust Edge. - A tripod table, the raised edge of

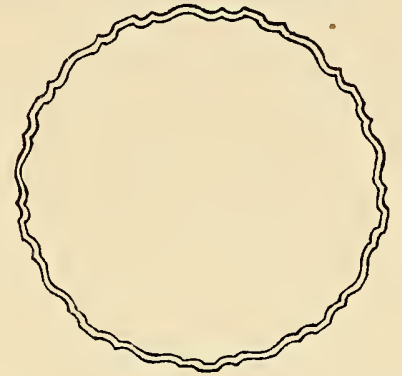

which is cut from the solid wood in cyma and simple curves.

Pier.-A table made to stand between windows.

Pillar \& Claw.-A table, the support of which is composed of a central column with three or four spreading feet shaped to resemble claws.

Refectory.-An early long, narrow table upon which was served a meal. 
Table.-Continued.

Rudd.-Same as Table-Dressing, which see.

Serving.-A long table intended to set against the wall from which to serve a meal.

Sewing.-A table with drawers fitted with compartments to hold sewing articles.

Side. - A long table, usually with drawers, intended to stand against a wall.

Sideboard. - A long table intended to stand against the wall, upon which to display plate, or from which to serve a meal.

Slate. - A table with a slate top surrounded with a broad frame ornamented with marquetry.

Sofa.-A long narrow table finished on all sides; intended to stand beside a sofa.

Table-Board. - See Table Trestle.

Tea.-A small low table intended to hold tea utensils.

Tilt-top.-A table, the top of which can be tilted to a vertical position.

Tray-top.--A tripod table with a round top encircled by a raised edge cut from the solid.

Trestle. - An early form of
TABLE.-Continued.

table with a movable top; supported on trestles. Called a Table-board.

Tripod.-A table, the support of which is composed of a column and three spreading legs.

Turned.-A table, the legs or legs and stretchers of which are turned.

Writing.-A flat top table upon which to write.

$X$ Braced. - A table with crossed stretchers.

Nest of.-A series of tables of such size that when not in use they can be set one inside another. Sometimes called "Quartetto."

TABOURET.-A small stool shaped like a drum.

TAmbour. - Narrow parallel strips of wood mounted continuously on cloth and made as a slide to cover pigeonholes, drawers or cupboards.

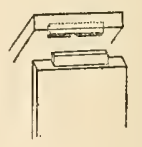

Tenon.-The cutting of the end of the rail so that it will fit into the mortise of the stile.

Tester.-The top of a bedstead supported by the four posts. This is entirely upholstered, 
Tester.-Continued. entirely of wood or with a moulding of wood often elaborately carved.

Thumb Moulding. - See Moulding.

TILL.-A small drawer or receptacle.

Tongue.-A continuous ridge left on the edge of a plank in-

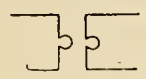

tended to fit into a groove cut into another plank.

TORCHÈrE.-A tall stand intended to hold candles.

Torus.-See Moulding.

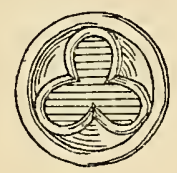

Trefoll.-An opening having three lobes separated by cusps.

TRIGLYPH.-Ornaments repeated at equal intervals, consisting of

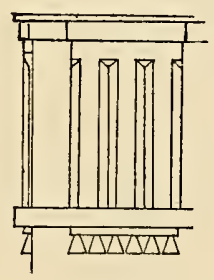

two channels and two half. channels. Found in the Doric frieze.
TUdor Rose.-An ornament in the form of a rose, used on early oak pieces.

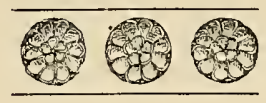

Tulip Pattern.-An ornament in marquetry or carving more or less closely resembling a tulip.

TURKEY WORK.-A covering composed of a coarse material upon which a pattern is worked in worsted by passing small pieces of worsted through the material and knotting them. So-called because often made to resemble Turkish rugs.

Turning.-The process of giving circular or other forms to wood by causing them to revolve in a lathe and applying cutting instruments.

Bulbous.-A turning in bulb form. See Leg, Bulbous, Turned.

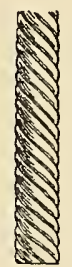

Cable.-A turning made to resemble a cable.

$K n o b$. - A turning made to resemble knobs. See Leg, Knob, Turned. 


\section{GLOSSAR Y}

Turning.-Continued.

Sausage.-A turning made to

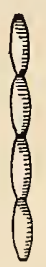

resemble contiguous elongated ovals.

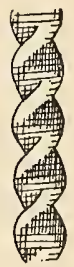

Spiral-Twist.-Turning made to resemble a corkscrew.
Turning.-Continued:

Vase, Ring \& Bulb.-Turning which resembles a vase

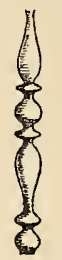

separated by a ring from a bulb-shaped turning.

Twisted Column.-A column, the shaft of which is spiral turned.

Turtle-Back.-See Boss.

UNDERBRACED. - Legs strengthened with stretchers. 


\section{$\mathrm{V}, \mathrm{W}$}

Valance.-The drapery hanging Warming Pan.-A metal pan about a bedstead.

VENEER.-A thin strip of wood applied to a surface.

Vitruvian Scroll.-See Scroll.

Volute.-A spiral scroll used in the Ionic, Corinthian and composite capitals.

WaInscot.-The word is derived from the low German word Wagenschot and signifies the best kind of oak timber well grained and without knots. with a cover and long handle. Within hot coals were placed and the pan was then placed between the sheets to warm the bed.

Woop.

Hard.-Generally speaking, the hard woods belonging to the broad leaf deciduous varieties.

Soft--Generally speaking, the soft woods belonging to the coniferous varieties. 
OF THIS BOOK THERE HAVE BEEN PRINTED AT THE GILLISS PRESS, TWENTY-F,IVE COPIES ON NORDELING HAND-MADE PAPER FOR THE MEMBERS OF THE WALPOLE SOCIETY, AND ONE HUNDRED AND SEVENTY-FIVE COPIES ON CHELTENHAM DECKEL-EDGE PAPER FOR GENERAL DISTRIBUTION

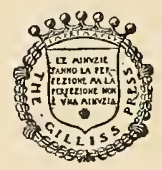








SMITHSONIAN INSTITUTION LIBRARIES

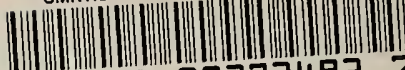

39088002734937

The furniture collectors' glossary 